\title{
PRELIMINARY GEOLOGIC SITE SELECTION FACTORS FOR THE NATIONAL WASTE TERMINAL STORAGE PROGRAM
}

\author{
June 1977
}

Woodward-Clyde Consultants

Three Embarcadero Center, Suite 700

San Francisco, California 94111

This report was prepared by Woodward-Clyde Consultants under subcontract 86 Y-165317 with Union Carbide Corporation, Nuclear Division. The subcontract was administered by the Office of Waste Isolation.

OAK RIDGE. TENNESSEE.

prepared for the U.S. ENERGY RESEARCH AND DEVELOPMENT ADMINISTRATION under U.S. GOVERNMENT Contract W-7405 eng 26

This informal document contains information which is preliminary and may be fragmentary or of 1 imited scope. The assumptions, views, and conclusions expressed in this document are those of the author and are not to be interpreted as those of Union Carbide Corporation, Nuclear Division, or USERDA. 


\section{DISCLAIMER}

This report was prepared as an account of work sponsored by an agency of the United States Government. Neither the United States Government nor any agency Thereof, nor any of their employees, makes any warranty, express or implied, or assumes any legal liability or responsibility for the accuracy, completeness, or usefulness of any information, apparatus, product, or process disclosed, or represents that its use would not infringe privately owned rights. Reference herein to any specific commercial product, process, or service by trade name, trademark, manufacturer, or otherwise does not necessarily constitute or imply its endorsement, recommendation, or favoring by the United States Government or any agency thereof. The views and opinions of authors expressed herein do not necessarily state or reflect those of the United States Government or any agency thereof. 


\section{DISCLAIMER}

Portions of this document may be illegible in electronic image products. Images are produced from the best available original document. 
This report was prepared as an account of work sponsored by the United States Government. Neither the United States nor the Energy Research and Development Administration, nor any of their employees, nor any of their contractors, subcontractors, or their employees, makes any warranty, express or implied, or assumes any legal liability or responsibility for the accuracy, completeness or usefılness of any information. apparatus. product or process disclosed, or represents that its use would not infringe privately owned rights. 


\section{WORKING DRAFT}

\section{PREFACE}

This is a Working Draft Report prepared in response to Union Carbide Corporation, Nuclear Division, Order No. 86Y-16531V, Charge Order "C", effective May 18, 1977, which required Woodward-Clyde Consultants to provide a Working Draft Report by June 3, 1977. 
WORKING DRAFT

TABLE OF CONTENTS

1.0 INTRODUCTION $\quad \cdots \quad 1-1$

1.1 Background 1-1

1.2 Scope $\quad \therefore \quad 1-1$

2.0 HIERARCHY AND DEFINITION OF TERMS 2-1

3.0 GEOLOGIC CONSIDERATIONS AND FACTORS 3-1

3.1 Genera1 $\cdots 3-1$

3.2 Depth for Isolation 3-3

3.3 Dimensions 3-14

3.4 Tectonic Stability. 3-23

3.5 Hydrology 3-36

4.0 AN ILLUSTRATION OF AN APPROACH OF HOW GEOLOGIC SITING

FACTORS ARE APPLIED TO QUALIFY A SITE 4-1

4.1. Introduction 4-1

4.2 Approach 4-1: 


\section{WORKING DRAFT}

\subsection{BACKGROUND}

The Energy Research and Development Administration (ERDA) has the responsibility of locating, constructing, and operating federal repositories for the safe disposal of the nation's radioactive wastes. In February 1976, ERDA announced an expanded waste management program designed specifically for radioactive waste produced by commercial nuclear reactors. Called The National Waste Terminal Storage (NWTS) Program, its principal objective is to provide federal repositories. in various deep geologic formations at multiple locations in the United States in order to safely. dispose of the waste from commerial nuclear reactors.

The concept of geologic disposal relies on geologic isolation to assure that the radioactive waste does not become a hazard to the public health and safety. Because of the importance of the geologic environment in this concept, the purpose of this draft report is limited to listing and describing only the geologic considerations and the associated factors that have to be addressed in the selection of repository sites.

\subsection{SCOPE}

We understand that this report is intended primarily to serve as a basis for discussion between the Office of Waste Isolation'(OWI) and 


\section{WORKING DRAFT}

ERDA concerning site selection. Included in the scope of this report are the following:

- A description of the geologic considerations and the associated factors pertinent to the selection of repository sites.

- A description of the information necessary to assess the geologic factors.

- A description of how the necessary information can be obtained.

- An illustration of a general approach of how the geologic factors could be applied and integrated to asșess the acceptability of candidate sites.

Specifically excluded from the scope of this report are the following:

- A detailed description of how the geologic factors will be applied and integrated to assess the acceptavility of candidate sites; and

- A.definition of the criteria associated with each factor that will be used to judge the acceptability of the sites.

This report is based on a review of literature pertaining to the siting of a waste repository as well as the experience of Woodward-Clyde Consultants in site selection. 


\section{WORKING DRAFT}

The hierarchy and the definition of terms used in this report are shown in Figure 2.1 and discussed below.

GOAL:

SITING OBJECTIVES:
The end which site selection efforts are ultimately striving to attain.

For this report, the goal is to isolate the radioactive waste from the biosphere.

The subgoals of site selection.

For the NWTS program, there are three broad siting objectives; the first objective is the most important and must be achieved before the other objectives may be addressed.

1. To select sites with characteristics that will assure the public health and safety.

2. To select sites with characteristics that will permit construction and operation of a repository with acceptable environmental and social impacts.

3. To select sites with characteristics that will permit construction and operation of a repository at acceptable cost. 
TO ISOLATE RADIOACTIVE

WASTE FROM BIOSPHERE

Siting

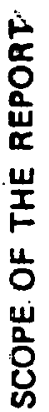

Objective

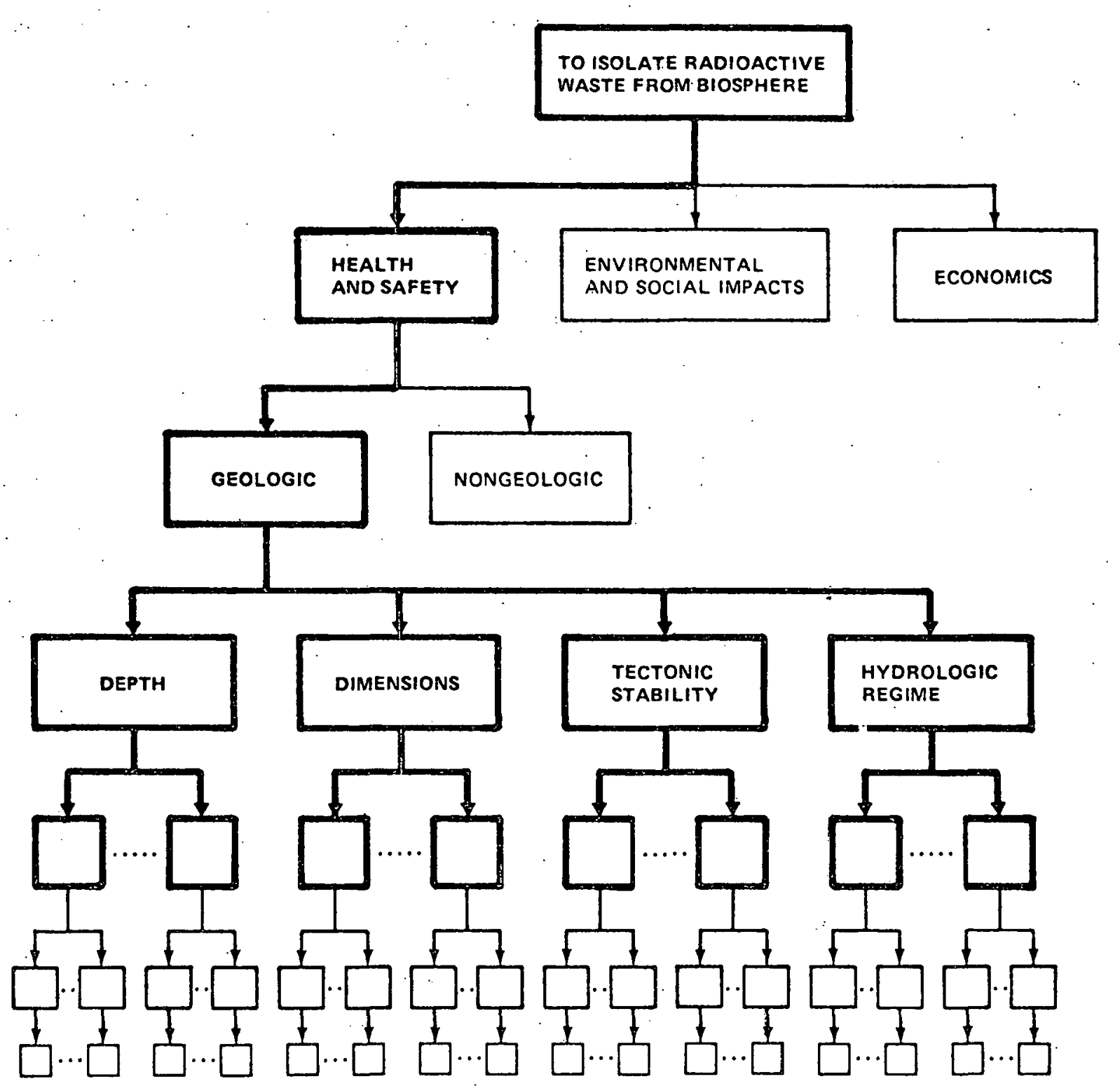

Factors

Measures

Criteria 


\section{WORKING DRAFT}

In this report, only the geologic aspects of the first siting objective will be discussed. The geologic portion of this first siting objective may then be stated as follows: To locate a host rock that shall isolate the radioactive waste so that it does not become a hazard to the public health and safety.

SITING CONSIDERATIONS: The broad technical basis for selecting a repository site in order to achieve the siting objective.

To achieve the geologic siting objective just stated, there are four geologic siting considerations:

1. The host rock shall be at a depth sufficient to separate the repository from natural surficial processes in order to assure geologic isolation.

2. The host rock shall be a volume of rock with dimensions, properties, and characterlstics adequate to assure geologic isolation.

3. The tectonic stability of the geologic environment shall be sufficient to assure geologic isolation.

4. The hydrologic regime of the geologic environment shall be such as to assure geologic isolation. 


\section{WORKING DRAFT}

SITING FACTORS:

MEASURES:
The specific technical basis for selecting a repository site.

In this report, siting factors are generated and organized as a group under each siting consideration. For example, stream erosion and glacial erosion would be geologic factors associated with the siting consideration pertaining to the depth of the host rock. A listing and a description of the siting factors for the four geologic siting considerations are presented in Section 3.0.

The achievement of each siting consideration would require evaluation of the factors, sometimes interacting with each other, as a group. An illustration of a general approach to evaluating the factors for one geologic siting consideration is described in Section 4. Parameters used to rate the positive or negative contribution of each factor in terms of the siting objective.

For example, to assess the relevance of geologic faulting in a particular location, "measures such as the distance from a candidate site to a fault and the seismic activity history of the fault would be used. In some cases; a factor has only a single measure to assess the significance to the siting objective. Ordinarily, two or more measures will be required to provide a complete assessment of how a factor such as geologic faulting will affect health and safety objectives for a particular location. 


\section{WORKING DRAFT}

The scope of this report does not include the identification and description of all of the measures appropriate to each geologic factor. However, in the process of describing the geologic factors in Sections. 3 and 4 , some examples of measure are introduced for illustrative purposes.

CRITERIA:

The limiting values, generally expressed quantitatively, that are placed on the measures to determine which values on a given measure are acceptable with respect to its siting consideration.

It is important to distinguish between two types of siting criteria, site screening criteria and site qualification criteria, each reflective of different but closely related concepts in site selection.

Site screening criteria are those applied during the site selection process to search for a potentially acceptable site. Generally, site selection involves a screening process whereby larger geographical areas are systematically "screened" and portions of the area are excluded from further consideration in order to narrow its search to smaller and smaller areas to locate candidate sites. Excluding an area on the basis of certain site screening criteria does not necessarily mean that the area contains no acceptable sites, it merely means that the area has a low probability of containing such sites. The purpose of the site screening 
is primarily to focus the search. as rapidly as possible on those areas that have the highest probability of yielding acceptable sites.

Site qualification criteria, on the other hand, are used once a candidate site has been identified to assure that the candidate site meets the overall siting objectives. Site qualification criteria, therefore, represent standards upon which a specific candidate site is judged as to its acceptability. The geologic siting factors described in this report are common to both consepts. 


\section{WORKING DRAFT}

3.0

GEOLOGIC CONSTDERATIONS AND FACTORS

\subsection{GENERAL}

Table 3.1 presents a matrix identifying the relationship of the geologic siting factors to the four principal geologic siting considerations. Detailed descriptions of the primary factors are presented in Sections 3.2 through 3.5. They are organized according to the siting considerations. Included in each description is a brief indication of the type of information and data needed to assess the geologic factors as well as an indication of the source of data.

The geologic siting factors are applicable for either site selection or site qualification purposes. No attempt has been made to provide any listing and description of the corresponding measures. However, in some cases, to describe a geologic factor, measures may be introduced for purposes of clarification.

The list of geologic siting factors is limited to the consideration of credible geologic events that might potentially affect the location of the host rock. Noncredible events such as extraterrestrial events, e.g., impact from a meteorite or shift of the earth's axis or magnetic field, have not been taken into account in this report. 
Table 3.1. GEOLOGIC FACTORS AND CONSIDERATIONS

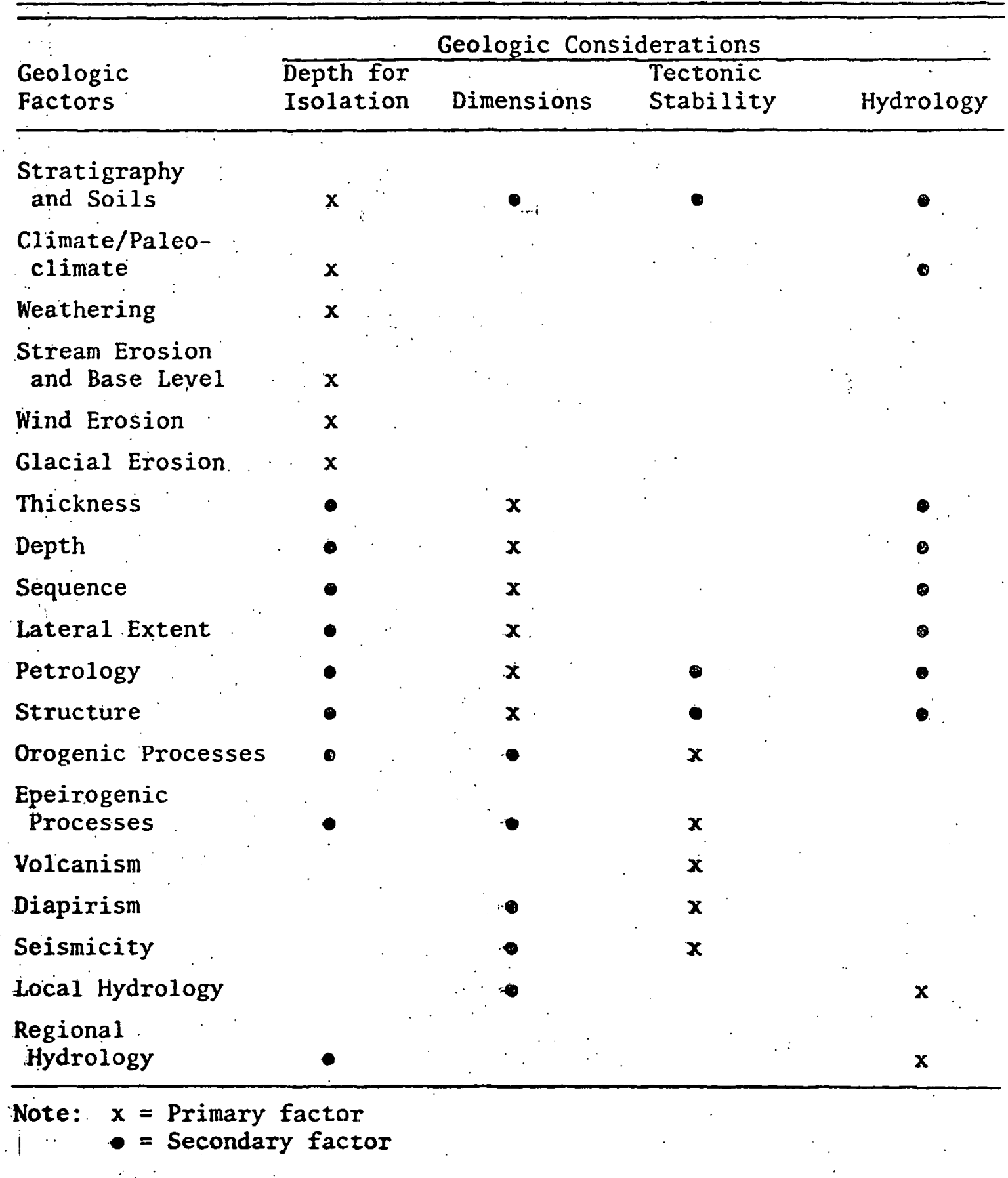




\section{WORKING DRAFT}

\subsection{DEPTH FOR ISOLATION}

The host rock shall be at a depth sufficient to separate the repository from natural surficial processes in order to assure geologic isolation.

Discussion

This consideration is important to prevent natural surficial processes from exposing the repository. The types and rates of surface processes which could remove rock overlying the repository must be considered to assure that the repository remains intact to isolate the waste from the biosphere.

Erosion is a process that affects all exposed land areas of the earth. Material is removed from all exposed surfaces either intermittently or continually. In many areas, other material is deposited intermittently. Where deposition exceeds erosion, the land is built up; however, where exosion exceeds deposition, material is removed and the subsurface becomes exposed.

To assure that surface processes do not affect the repository, all the rock units between the surface and base level must be considered along with the depth of the repository. The weathering characteristics of the rock must be considered to determine the character of each formation or bed with respect to near-surface processes which break solid rock down into a form that can be transported. It is also necessary to consider the types of surface processes which transport the rock material and the rates at which material may be removed. Tectonic rates of uplift or subsidence must be considered insofar as they affect base level and erosion.

Baseline data to evaluate the factors will be developed chiefly from historic time. Quaternary-Holocene geologic and paleoclimatic data will be required to evaluate the effect of long-term climate changes. 


\section{WORKING DRAFT}

Posisible climate changes must be considered and discussed to assure that all credible events have been considered.

Base level is a key factor and is ultimately dependent on sea level. Near the ocean, base levei changes with eustatic sea level; however, further inland, cyclic sea level changes are less effective and tend to be averaged out. Of more importance inland are temporary base levels due to mountains, dikes, large rock sills, or dense rock layers. These features may "hold up" a base level for periods of geologic time that approximate the waste isolation period.

Stream erosion rates are generally high when the land surface is high above base level and tend to approach zero as the land surface approaches base level.

The processes that operate independent of base level are glacial and wind erosion. In general neither process is known to erode downward more than a few hundred feet. Site confirmation studies of the physical properties of the rock and possible paleoclimate variations would have to be made to verify that this generalization would be valid at a selected site.

The factors pertinent to evaluating the depth of the host rock for isolation of radioactive waste are shown in Figure 3.1 and described below.

Stratigraphy and Soils. The stratigraphic sequence, rock types, rock characteristics, relationship to overlying and underlying rocks, and nature of geologic contacts are the primary factors in assessing the adequate depth to the host rock. Consistency, uniformity, and homogeneity of the various rock types are necessary for the determination of denudation rates under various erosional processes. Open fractures, joints, and other structural features accelerate these processes. Depending on the type of weathering and erosional processes, the duration of erosion and the intensity of each process, they could have significant effects on the overburden. 



\section{WORKING DRAFT}

Data Needs. The data needed to evaluate how stratigraphy and soils would influence the assessment of an adequate depth to the host rock are some of the following:

- Subsurface geologic section

- stratigraphy/rock type(s)

- elevation

- thickness

- physical characteristics of each rock unit

- nature of geologic contacts

- Surface and groundwater hydrology

- Historical weather

- Historical geology (1iterature search)

- effects of surficial weathering and erosional processes on various soil and rock types through geologic time

Data Sources: Sources of information needed to evaluate the influence of stratigraphy and soils on depth of host rock are listed below. This list is not meant to include all of the sources available or to indicate that each of the sources listed must be utilized. It is a check list of some well known and reliable sources including methods of investigation of surficial material and subsurface stratigraphy.

- I.iterature search

- Existing bore-hole records

- Geophysical methods

- seismic refraction.

- deep resistivity

- Mapping

- surface field mapping

- subsurface mapping from existing bore-hole information

Drilling and logging (coring)

- Sampling 


\title{
WORKING DRAFT
}

\author{
- Laboratory testing \\ - soil testing \\ - rock testing
}

Climate and Paleoclimate. The earth's climate has changed many times in the past. Climatic conditions provide the energy for the processes of weathering and erosion. The erosional rate and intensity vary in differing climatic conditions. In the last several million years, the earth has experienced a succession of warming and cooling trends, each lasting for about 100,000 to 200,000 years. The temperature and rainfall of these periods provided directly or contributed to the physical forces which acted upon rock surfaces, either breaking them or transforming their composition. These major climatic variations generally accompanied the onset of glacial and interglacial periods. An assessment of historic and future climatic trends will provide the basis as to whether glaciation may occur at a specific site and thus influence the depth to host rock.

Data Needs. Records of all known past and present climatic conditions are required for extrapolation to predict possible future climatic variations that may affect the overburden in the area of the host rock. The types of information necded concerning past and present climate include some of the following:

- Temperature (mean and extreme)

- Barometric pressure

- Humidity

- Wind patterns

- Windspeed and direction (mean and extreme)

Sunshine and solar radiation

- Precipitation

Evaporation

Seasonal effects 
WORKING DRAFT

- Frost depth

- Latitude

- Longitude

- Elevation

- Position with respect to ocean/global wind circulation patterns

Data Sources.

- Literature search

- Meteorologic records

- instrumental data

- preinstrumental data.

- Study of glacial features

Weathering. Weathering is a surface or near-surface process that physically or chemically breaks rock down into components that can be removed by surface erosional processes. Weathering at any location is generally a function of climate, rock type (structure), topography, and vegetation. Different rock types break down in different but generally predictable ways based on the interaction of the factors mentioned above. Through geologic time, weathering makes a significant contribution to the erosional processes involved in denudation.

The chief chemical weathering processes are hydration, hydrolysis, oxidation, carbonation, and solution; generally, these processes are more important than physical weathering. Chemical weathering results in an increase in bulk with resulting strains and stresses within the nearsurface rocks. Lower density minerals with a smaller particle size are produced. Hence, such weachering increases surface area between rock particles and the surrounding media: resulting in generally stable minerals with greater mobility. Physical weathering processes include expansion due to unloading, crystal growth, thermal expansion, organic activity; and colloid plucking. 


\section{WORKING DRAFT}

Sedimentary rocks and evaporites are formed at or near the earth's surface. The minerals formed are generally stable at temperatures and pressures that exist near the surface, much the same as igneous or metamorphic minerals are stable at their respective temperatures and depths of formation.

In the case of sedimentary rocks, primary minerals are formed from precipitation of minerals in water. Other mineral grains in sedimentary rock have been eroded from igneous, metamorphic, or other sedimentary rocks. Through time, the weathering processes change many of the igneous and metamorphic minerals to minerals that are more stable near tho earth's surface.

Data Needs. The following tabulation describes the general information needed to determine the effect of climate on the weathering rate of a given rock. This list is not meant to be comprehensive; it simply shows some of the properties of rock that must be considered in order to establish possible rates of weathering through geologic time.

- Petrologic descriptions of each rock type, 1isting minerals

- Physical dimensions of the individual minerals and their relation to each other

- size

- shape

- cleavage

- crystal structure

- bonding

- cementation

- Characteristics of the rock that are pathways for weathering agents

- existing joints

- foliation

- bedding

- dip

- fractures 


\section{WORKING DRAFT}

- Chemical properties of individual minerals in the rock

- Weathering rates for various rock types under different climatic conditions

\section{Data Sources.}

- Geologic literature

\section{Stream Erosion and Base Level}

Stream erosion includes all related processes that allow rock material to be removed from the area of a repository by streams. The basic mechanism of stream erosion involves the following: the acquisition of loose material, the wearing away of bedrock through impact of rock material in transit, the mutual wear of rock particles against each other while in transit, and transportation (by traction, suspension, or solution of the acquired rock debris).

To assess the effects of stream erosion on the depth of host rock, the base level in an area must be established. Base level is an imaginary surface below which the stream or its tributaries cannot erode. The ultimate base level is sea level.

Away from the sea, in the interior of the continent, natural surficial processes occurring over a long period of time may establish temporary base levels which may last from a few hundred to millions of years. An example of this would be a plateau. of interest in siting a host rock is determining the temporary base level and predicting its permanency at a specific location in order to establish the appropriate depth to host rock.

A major parameter needed to assess how long a temporary base level will be maintained is the rate of erosion in the area. 


\section{WORKING DRAFT}

Data Needs. The information needed to predict the rates of erosion that could occur near the host rock includes some of the following:

- Climatological characteristics of the region

- Stream flow and gradient

- Historic rates of exosion

- Geologic conditions including rock type and characteristics and stratigraphy

- Topographic features

- Surfaces and groundwater characteristics

\section{Data Sources.}

- Literature search

- Geologic mapping

- surface

- subsurface

- Field surveys

- Air photo interpretative studies

- Climate and paleoclimate studies

Wind Erosion. The three basic mechanisms of wind erosion are abrasion or corrasion, the natural sandblast action of windblown sand; deflation, the lifting and removal of loose material from the earth's surface; and attrition, the mutual wear of particles carried along by the wind. Wind erosion is of interest in evaluating the adequate depth of host rock in that the mechanism of deflation has the capability to erode below the base leivel.

Deflation has been known to be responsible for the formation of many depressions called blowouts. For example, the Great Plains region extending from Montana to Texas is the site of tens of thousands of such depressions that range in size from mere dimples that are a foot or two deep and not more than 10 feet in diameter to others that are scores of feet deep and several miles wide. The largest known possible blowout is several miles long and a few hundred feet deep. 


\section{WORKING DRAFT}

Data Needs.

- Wind velocity, duration, fetch, and load

- Regional climatic characteristics

- Geologic conditions including rock type and characteristics and stratigraphy

- Topographic characteristics.

\section{Data Sources.}

- Literature search

- Studies of areas where wind is actively eroding today

- Geologic studies

- rock type

- thickness

- characteristics

- Wind velocities, duration, fetch, load

Glacial Erosion. Glaciers are bodies of ice consisting mainly of recrystallized snow, flowing on the land surface. Glacial ice is very active, receiving nourishment in the form of snowfall and giving up water by melting. The fate of any glacier depends on how much ice melts and how much is replaced by new snow. That, in turn, depends on climate. In the last one million years, there have been four glacial periods. Apart from the critical role they play in the water cycle, glaciers flow across land areas, erode land, transport eroded rock material, and deposit it elsewhere. Glaciation has been known to erode to depths of several hundred feet.

The effects of glacial erosion are dependent on ice temperature, rock, rock structure, and energy available (climate and gravity, a function of topography).

Since this is another process that is capable of eroding below base level, it is important to evaluate the lower limits of glacial erosion. 


\section{WORKING DRAFT}

Data Needs.

- C1imatic characteristics, particularly paleoclimate

- Topography

- possible gradient of ice surface to determine velocity of ice movement

- possible depth of ice

- extent of ice

- Physical characteristics of rock that allow pieces of rock to be separated and removed

- jointing

- parting

- dip

- Physical characteristics of rock that allow it to be abraded

- hardness

- mineral content

- crystal or particle size of components

- cement

- Physical characteristics of glacial ice that affect erosional rates

- ice temperature

- gradient

- thickness

Data Sources.

- Climatological records

- Geologic literature

- Field mapping 


\subsection{DIMENSIONS}

\section{WORKING DRAFT}

The host rock shall be a volume of rock with dimensions, properties, and characteristics adequate to assure geologic isolation.

Considerations discussed in other sections of this report are concerned with external processes that may affect the host rock. This consideration of dimension deals with the effects that the repository may have on the host rock and surrounding formations. The factors to be considered here deal with establishing the volume or minimum lateral or vertical dimension of acceptable host rock which would be required to physically contain the anticipated waste volume and to limit any predictable rock deterioration to areas within the host rock. (see Figure 3.2).

The interaction between engineering factors and geologic factors must be considered in determination of the minimum dimensions of the host rock: depth below surface and the volume of host rock (lateral dimensions, thickness).

\section{Discussion}

The consideration of acceptable host rock dimensions contains both geologic and engineering aspects. The consideration will probably be resolved by a series of iterations which alternately consider the engineering and geologic factors. To identify and summarize the geologic aspects of the consideration, identification of some of the engineering factors must be included in this discussion.

The most significant engineering problems are associated with management of the thermal loading of the host rock by the waste during storage and isolation phases. Using the physical and thermodynamic properties generally characteristic of various rock types, the designer can establish a preliminary relationship between volume of host rock and a range of acceptable depths required to construct a repository, for a given host rock. The length and width of the underground repository 



\section{WORKING DRAFT}

would be based primarily on the heat transmissibility of the rock, the volume of waste to be stored, and on the safety considerations required during excavation and operation of the repository. The depth to the selected repository level(s) would consider the change of lithostatic pressure with depth and the corresponding influence of lithostatic pressure on the physical and thermodynamic properties of the host and surrounding rock. The thickness of the host rock would reflect the vertical dimension required for repository openings, for the calculated or estimated rock creep or rock fracturing that typically accompanies mining, heat flow across host rock boundaries, temperature rise within the repository, thermal expansion of the host rock and its overall effect on the mine openings, and an additional thickness as a safety factor. After completion of an engineering iteration, the engineering factors of rock strength, heat transmissibility, lithostatic pressure, and the rock moduli would be translated to the corresponding geologic analogs, such as depth, rock type, baseline heat flow, mineralology, host rock thickness, and host rock extent.

Thus, the preliminary selection of a rock type, taiget depth, and other target dimensions are established to meet engineering as well as geologic needs, with a succeeding iteration identifying a minimum volume of the specified host rock in an acceptable geologic situation. The geologic factors which are strongly influenced by engineering aspects are:

- Depth of host rock within target limits

- Thickness of host rock within target limits

- Sequence and dimensions of significant layers above and below host rock

- Lateral extent of host rock and significant layers

In nature, rocks are not homogeneous and the properties identified with a given rock type can vary due to small differences in composition, texture, structure or to the processes that have affected the host rock through geologic time. Thus, an evaluation of the host rock is required 


\section{WORKING:DRAFT}

to evaluate the geologic factors described below, and to ascertain that the impact of the geologic factors on the thermodynamic or physical rock properties and the various rock moduli used for engineering evaluations and decisions will be within acceptable limits. In short, any geologic factors that may affect the overall integrity of the host rock or other rock within or near the established dimensions of the repository should be identified and evaluated. The geologic factors which must be evaluated independently of the engineering aspects include:

- Petrology. of the host rock and significant rock formations above or below

- Structure of the host rock and significant rock formations above or below

\section{Relevant Factors}

Depth. The depth of the host rock, as well ias its previous history of burial or exhumation, will govern the in-situ stress field (1ithostatic plus residual) within the host rock. This stress field will in turn. have significant effect on the mineral and particle fabric of the rock, the persistence and dimensions of joints or partings, the ability of the host rock to respond to thermally or chemically induced mineralogic or phase changes, and on the mechanical behavior of the host rock. The depth of host rock, together with the thermal properties of it and overlying rock units, will control the heat flux at the ground surface and the amount of surface heave resulting from the heat flux.

Data Needs.

Depth to host rock

Previous burial or exhumation history of host rock

\section{Data Sources.}

Geologic mapping

- Borings

- Geophysical methods 
- In-situ stress measurements

- Access shafts

Thickness. The thickness of the host rock must be sufficient to contain the vertical dimension of the physical openings of the repository and the waste stored or isolated in or near those openings, and to accommodate or dissipate the rheological, geologic, thermochemical, or physiochemical alterations induced in the host rock by waste and repository to an acceptable value at the boundary of the defined host rock. The thickness of the host rock factor must include sufficient provision for variations in thickness due to the geologic environment under which the rock was formed or to which it has been subjected since the time of its formation.

Data Needs.

- Average thickness of host rock

- Variations in average thickness

- Thickness of significant lithologic zones within host rock

- Variations in thickness of significant lithologic zones within host rock

Data Sources.

- Geophysical methods

- reflection

- refraction

- downhole logging

-Geologic mapping

- Stratigraphic borings

Access shafts

Lateral Extent. The lateral extent of the host rock must be sufficient to provide space for the planned extent of the repository and to accommodate or dissipate the rheologic, geologic, thermochemical, physiochemical, or 
other alterations to the host rock which might be induced by either the waste or the repository, to an acceptable value at the boundary of the defined host rock. Consideration of the lateral extent must include provision for anisotropy of geologic and rheologic conditions or properties.

Data Needs.

- Latera] extent of host rock

- Lateral extent of significant iithologic zones within host rock

Data Sources.

- Geologic mapping

- Stratigraphic borings

- Access shafts or exploratory adits.

- Geophysical methods

- refiection

- refraction

- downhole logging

- deep resistivity

Petrology. Rocks are named and described on the basis of their gross mineralogy. However, much of their overall behavior is governed by the size and shape of the component particles, mineral grains or crystals, and by the arrangement of the components in the fabric of the rock. Petrologic study is required to determine the geometric, physical, and chemical characteristics of the host rock and significant rock units above and beneath the host rock, as well as establishing the range of variation within each class of characteristics.

Data Needs.

- Mineral components

- percentage of each mineral component 


\section{WORKING DRAFT}

- mineral or lithic grain size distribution

- mineral or lithic grain shape

- fabric

- texture

- intergranular pore space

- degree of hydration

- mineral or lithic grain microstructure

- intergranular cementation

- degree of alteration

- chemical composition

- inclusions of exotic or foreign substances

\section{Datá Sources.}

- Field sampling from outcrops, cuttings, or core samples

- Petrographic study of thin sections

- X-ray diffraction analysis

- Microprobe analysis

- Disaggregation of sedimentary rock followed by sedimentary petrologic analysis

- heavy mineral separations

- magnetic mineral separations

- isodynamic separation

- grain size analysis

- cement identification

- Literature compilation from technical publications

- Geochemical analysis and physical laboratory tests

Geologic Structure. The geologic structure of the host rock and significant rock units both above and below the host rock must be determined to a level sufficient to allow the interpretation of the previous geologic history of the host and surrounding rocks and to allow the engineering behavior of the host rock to be predicted or evaluated. 


\section{WORKING DRAFT}

Data Needs.

- Geometric descriptors (dip, strike, plunge) of:

- bedding

- foliation

- joints

- partings

- fractures

- shears

- folds

- Major structural elements

- faults

- diapirs

- plugs

- domes

- basins

- synclines

- anticlines

- Stratigraphic sequence of rock units, including the host rock and contiguous rocks

- rock type

- dimensions of rock unit

- depth below surface

- nriginal depositional conditions

- position relative to the host rock

\section{Data Sources.}

- Descriptions recnrded in the literaturc

- Geologic mapping.

- Direct field measurement

- Exploratory borings

- drill logs

- core logs and core measurements 


\section{WORKING DRAFT}

- Geophysical studies

- gravity surveys

- seismic refraction surveys

-.seismic reflection surveys

- resistivity surveys

- downhole geophysical logs

- electromagnetic surveys

- Photogeologic study 


\section{WORKING DRAFT}

\subsection{TECTONIC STABILITY}

The tectonic stability of the geologic environment shall be sufficient to assure geologic isolation.

In order to evaluate the tectonic history of the geologic environment which contains the host rock, and to use that geologic history to predict the long-term tectonic stability of the host rock, the tectonic processes which may deform the host rock and the surrounding environment must be identified; the rates of deformation must be measured or estimated; and the net effect of tectonic process on the potential host rock must be predicted and evaluated.

\section{Discussion}

The tectonic stability of the host rock will depend on a number of factors which may act either independently or collectively. The evaluation of the tectonic stability of the host rock environment would be based on both interacting and isolated factors (see Figure 3.3).

To evaluate the regional tectonic stability of the host rock's geologic environment, its tcctonic history must be evaluated and the significant structural features must be identified. Based on past geologic and tectoric evidence and events, the future events could be broadly extrapolated.

An evaluation of local and regional seismicity will give an insight into the deformation processes still active within the earth's crust and how they are affecting the overall stability of the geologic province within which the host rock lies.

Geologic evidence indicates that orogenic and epeirogenic processes typically take millions of years to complete. The time of isolation -required in the host rock is only a fraction of the time required to complete most orogenic or epeirogenic processes; therefore some prediction 


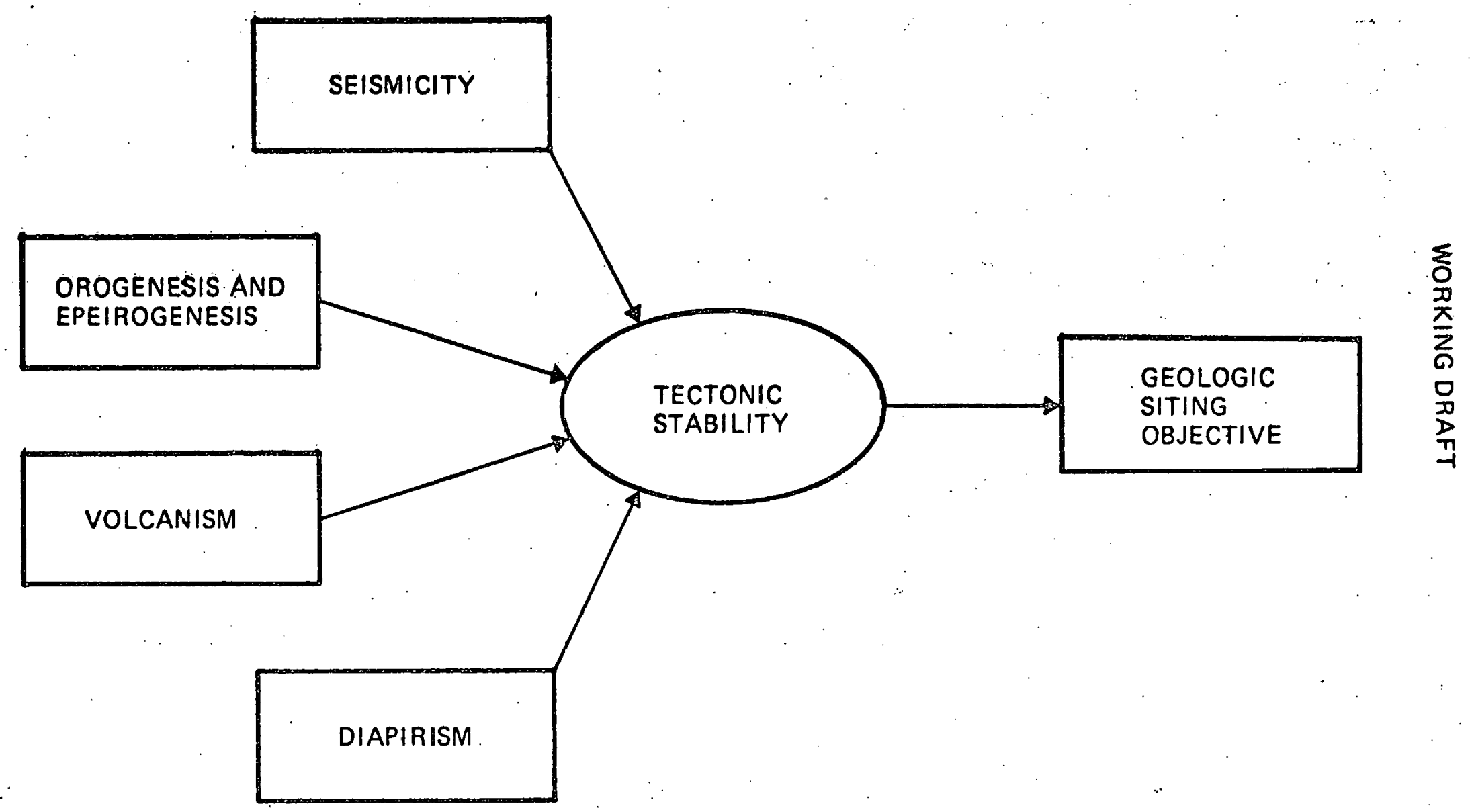

Figure 3.3 


\section{WORKING DRAFT}

of future deformation can be made, based on current rates of deformation and recent tectonic history. Evaluation of orogenic and epeirogenic processes might identify tectonic events which could affect the host rock.

The slow uplift or subsidence of 1 and masses may have an effect on the host rock through change in the regional erosion and denudation patterns of the area. Careful evaluation is required to differentiate isostatic adjustments due to periodic geologic or ice mass loading and unloading from ongoing tectonic uplift or downwarping.

Volcanism may be a significant factor in only a few of the many geologic provinces which may be considered in the search for acceptable host rocks. Generally each volcanic province has its own type or types of volcanism. Study of past volcanism within the province would provide evidence to assist in the evaluation of the significance of volcanism to the host rock environment, and establishment of the location, extent, and severity of future volcanic events.

In geologic provinces where they occur, diapiric structures should be inventoried and the geologic conditions which initiate and sustain diapirs in that geologic province should be identified. Some inactive diapirs may be considered as potential host rocks, while a reactivated or new diapir may disturb the predicted geologic conditions. Therefore, to assure the continued safety of existing diapiric host rock and to avoid potential host rock near possible future diapirs, the conditions and processes must be examined and understood.

The evaluation of tectonic stability of the host rock environment should consider the geologic and tectonic evidence in the area of the host rock and of the broad region of geologic and/or tectonic similarity which contains the host rock. This latter broad region is usually termed a province, and is characterized by having a number of elements of similarity throughout the province. Previous geologic evidence indicates that in a broad sense and on a long-term basis, the changes brought by 


\section{WORKING DRAFT}

geologic/tectonic processes within the various parts of the province will be similar. The elements whose similarities are generally used to establish a geologic/tectonic province include:

- Geologic History

- Structure

- Geomorpinology

- Topography

- Stratigraphy.

- Hydrology

- Volcanism

- Seismicity

Having established the tectonic history of the geologic/tectonic province within which the host rock lies, that past history may be used to broadly extrapolate future tectonic events. The effect of such future events on the host rock may then be evaluated on the basis of the behavior of the host rock to the past tectonic events. The basic premise (uniformitarianism) for such extrapolation is the accumulated body of geologic evidence which support the theory that the geologic processes and natural laws now operating to modify the earth's crust have acted in the same regular manner and with essentially the same intensity throughout geologic time, and the past geologic events can be explained by phenomena and forces observable today, This theory relates past conditions with present; it does not imply uniform rate of change and exclude minor local perturbations.

\section{Relevant Factors}

Factors which aid in definition and evaluation of the tectonic stability of the host rock include seismicity, orogenesis, epeirogenesis, volcanism, and diapirism.

Selsmicity. Seismic data are signiflcant to the evaluation of potential host rock units since they are used to dotemmine earthquake hazards and earthquake activity, active faults, volcanism, global tectonics, and the overall tectonic flux within a tectonic province. A seismically active 


\section{WORKING DRAFT}

area indicates that tectonic forces within the crust of earth are still operative and their intensity, frequency, and effects should be taken Into consideration for host rock evaluation within the area.

Microseisms indicate the tectonic flux within a tectonic province and potential locations of the larger seismic events, earthquakes, which are a hazard in themselves. Earthquakes and microseisms have been used to define active faults, folding, active volcanism, and active geothermal sources, as well as the larger structural elements of plate tectonic theory.

In some tectonic provinces the source of potentially damaging future earthquakes can be related to individual faults or fault systems. In other provinces, where earthquakes occur without surface faulting, the source of potential earthquakes cannot be as well defined. These earthquake hypocenters must be assumed either to be located at a great depth or the energy is dissipated in the geologic formations without surface faulting. Ground motion at a location can be related to earihquake magnitude and the distance from the causative fault or earthquake hypocenter. Another factor affecting the ground motion at a given location concerns the characteristics of soil and rock layers. The shear wave velocity can be used with the normal soils or rock engineering test data to estimate or compute ground motions in the various subsurface $i$ ayers. This computation also reflects. the magnitude of the causative earthquake and the distance from the site to the energy source.

Earthquakes are not usually thought of as hazards to deep openings, Most earthquake damage is observed in shallow zones or surface facilities but passage of seismic energy could structurally affect the rocks of the mine openings and the adjacent areas.

Data Needs.

- Local microseismic data

- Location of felt earthquakes in relation to the host rock

- Causative mechanism 


\section{WORKING DRAFT}

- Frequency of occurrence

- Earthquake magnitude

- Related tectonic processes

- surface fauits

- subsurface faults

- active faults

- inactive faults

- rifting

- volcanism

- Regional tectonic structures

- Characteristics of rocks at site

- shear wave velocity

- shear-strain characteristics

- Geologic evidence of past earthquakes

Data Sources.

- Historic records

- Instrumental records

- Geologic evidence of active faulting

-. geologic literature

- geologic maps, sections

- photographic interpretation

- remote sensing imagery

- field studies

- mapping--Quaternary-Holocene displacements

- trenching

- sampling

- age dating--paleomagnetic, $\mathrm{C}_{14}$

Geophysical evidence

- anamolies in geologically young material 


\section{WORKING DRAFT}

- Microseismic networks

- Geodetic evidence

- strain data from repeated geodetic surveys

- Technical publications

Orogenesis and Epeirogenesis. Orogenic processes result from geodynamic movement within the earth's crust over a regional, as opposed to continental, area. Orogenesis typically lasts a few hundreds of thousands to a few millions of years and may affect an area equivalent to a major mountain range or group of ranges. The orogenic movements generally produce the major geologic structures found within a region, such as folds, faults, and uplifted or downdropped structural blocks. Recurrence of the orogenic processes of folding, faulting, or uplifting and downwarping could adversely affect the host rock;

Faults constitute physical discontinuities with a rock mass and under appropriate stress conditions may generate seismic events. Displacement along faults cutting the host rock may adversely affect its ability to prevent significant transport of waste products to the biosphere. Faults may also act as groundwater barriers or flow paths; either one could have adverse effect on the host rock.

Folding or flexure under orogenic stresses may generate relative. movement between lithologic or structural units of the host rock, may result in the thinning or thickening of certain host rock units, or may cause the opening or closing of fractures with a resulting change in permeability.

Orogenic uplift or downwarping results from isostatic adjustment and/or subcrustal magma genesis. Uplift or downwarp will alter the stress fields within rock masses, alter the base level erosion pattern, increase or decrease the overburden loading on the host rock, and cause other potentialiy adverse geologic conditions. 


\section{WORKING DRAFT}

Epeirogenic processes are primarily vertical movements in earth crust and affect large areas of the continents producing plateaus and basins. The rates of movement are slower than orogenic rates and the processes may continue for long periods of geologic time. A special type of vertical movement, isostatic adjustment to local geologic loading or unloading is often superimposed on the ongoing epeirogenic processes.

These slow vertical movements in geologic time may cause erosional and denudation patterns. Loading and unloading of the crust by thick sedimentary accumulations in some areas and deep erosion in others produce minor adjustments in the crustal level. Slow rise in land level is observed in areas which were heavily loaded by thick glacial ice. This rise is a result of isostatic response to removal of load.

Study of the epeirogenic framework of major continental areas provides a broad framework within which the processes of lesser areal extent may be interpreted and evaluated.

Data Needs.

- Geologic history

- Geomorphology

- Topography

- Relationship of province with reference to other provinces and crustal structural elements (crustal plates)

- Stratigraphic profile

- Previous tectonic events

- Current rates of uplift or subsidence

- Component of rate due to tectonic processes

- Quatemary and Holocene geologic processes 


\section{WORKING DRAFT}

\section{Data Sources.}

- Evaluation of existing geodetic data

- leveiing

- triangulation

- gravity

- Evaluation of geologic history interpreted from Quatemary geolog,

- geomorphologic studies

- paleoclimate data

- sedimentation rates

- erosional rates

- apparent changes of base level

- Geologic mapping

- Geophysical surveys

- Age dating studies

Volcanism. Volcanic processes can be divided into the subsurface processes that bring magma through the crust of the earth in fissures or conduits and the related surface phenomena, as the magma is gently or explosively extruded or ejected as flows and tephra or ash. Except during the limited time surface facilities are in operation, the surface phenomena should have little significant effect on the host rock. The subsurface phenomena would only be significant if a fissure, conduit, or near surface intmusion occurred in or adjacent to that portion of the host rock which contains the repository.

There are many types of volcanism known throughout the world; however, each tectonic province is generally characterized by recurrences of the same general types of volcanism that have occurred there in the past. Thus the study of volcanic hazards would be oriented toward collection and evaluation of data for the tectonic province containing the host rock. 


\section{WORKING DRAFT}

Data Needs.

- Type(s) of volcanism or magmatic intrusions

- flood basalt

- fissure flow

- Cataclastic events

- fissure ash eruption

- diking

- laccolithic intrusion

- Composition or types of volcanic rock produced

- basalt

- rhyolite

- andesite

- Source location and type

- volcanic conduits

- rift zones

- fissures

- Relationship of vents to other tectonic structures

- older fissures

- active faults (active at time of volcanic eruption)

- preexisting inactive faults

- zones of structural weakness (1ines of volcanoes)

- tectonic province boundaries

- Age of extrusion

\section{Data Sources.}

- Field mapping

- Photo interpretation

- Geologic maps

- Geologic publications

Petrographic analysis

- Age dating studies 


\section{WORKING DRAFT}

Diapirism. Diapiric structures in sedimentary rock result from tectonic or unbalanced geostatic forces acting on a stratum of rock which possesses plastic behavioral properties. The diapiric process may be initiated by imbalance of geostatic pressure, by applied tectonic stress, by tectonic heating, or by a combination of these elements.

Normally the process proceeds to an equilibrium point, leaving a dome or anticline of the diapiric rock at some elevation above the depth at which the diapiric flow was initiated.

Diapirs and diapiric processes are significant for two reasons: (1) inactive diapiric structures may be considered as potential host rock, and (2) the potential for development of future diapirs or reactivation of existing diapirs must be considered in some geologic/tectonic provinces.

Certain rock properties change with changes in pressure, temperature, and water content. In the case of the rock types that commonly form diapiric structures, the property that changes is their apparent plasticity.

At near surface temperatures and pressures, the rocks that form diapirs normally behave as brittle materials; however, if subjected to the geostatic pressure produced by several thousand to tens of thousands of feet of rock loading, and if the confining forces become unbalanced, they may behave as pastic materials.

The evaluation of diapirism within a geologic province requires detailed knowiedge regarding the causal mechanism of past diapirism, the material and behavioral properties of the host rock and rock units beneath the host rock, and the geologic and tectonic changes that are predicted from the past geologic and tectonic history.

Data Needs.

- Geometry of layered or diapiric rock

- depth and thickness of each potentially diapiric bed 


\section{WORKING DRAFT}

- nature of rock layers above and below potentially diapiric beds

- laterai extent

- position of potentially diapiric beds relative to the host rock

- attitude of beds relative to the 1 and surface

- geometry of the diapir and abutting rock layers, if considered as a host rock

- Stratigraphic column

- rock types

- rock properties

- History of diapiric emplacement, if any, from each potentially capable layer

- Knowledge of the cause and occurrence of diapixs within the province

- Nature of grounfwater regime

- caprock

- aquifers

- brine occurrence

- Rate of diapiric movement

\section{Data Sources.}

- Location and geometry

- geologic maps

- Iiterature search

- seismic surveys

- gravity surveys

- drilling and logging

- geochemical studies

- Rock properties

- technical publications

- in-situ tests

- Maboratory tests 


\section{WORKING DRAFT}

- History of diapirs within the province

- technical publications

- geologic mapping

- age dating studies

- Rate of diapiric movement

- geologic mapping

- geodetic leveling

- age dating studies

- microseismic studies

- geophysical surveys

$\because$ geochemical studies 


\section{WORKING DRAFT}

\subsection{HYDROLOGY}

The hydrologic regime of the geologic environment shall be sufficient to assure geologic isolation.

Groundwater is considered a primary transport medium and must have complete definition relative to any candidate host rock. It is, therefore, imperative that the hydrologic regime within which the host rock is located be thoroughly understood.

To accomplish this the hydrologic characteristics of the geologic environment must be examined to ascertain if groundwater is in contact with or hydraulically connected through the candidate host rock.

\section{Discussion}

Groundwater investigations will include definition of the systems both above and below the candidate host rock. This includes a determination of the hydrologic sharacteristics for each part of a potential host system and an assessment of hydraulic interconnections. The hydrologic studies will necessarily be most detailed near the repository to assure that all conditions which may affect the repository will be considered. The studies will be extended, with less emphasis on detail, to include the regional hydrologic framcwork in order to identify remote conditions that may affect the local system. (see Figure 3.4).

The relevant studies required to develop a thorough understanding of a given hydrologic regime are: (1) a detailed investigation of the local geohydrology and (2) a less detailed investigation of the regional geohydrology. The local geohydrology consists of aquifers and confining units, and/or combinations of interconnected aquifers and confining units. The hydraulic relationship between these units, including the host rock, which may be located between confining units or in itself be a confining unit, can be established by geologic and hydrologic testing and water quality (water chemistry and geochemistry) studies. 


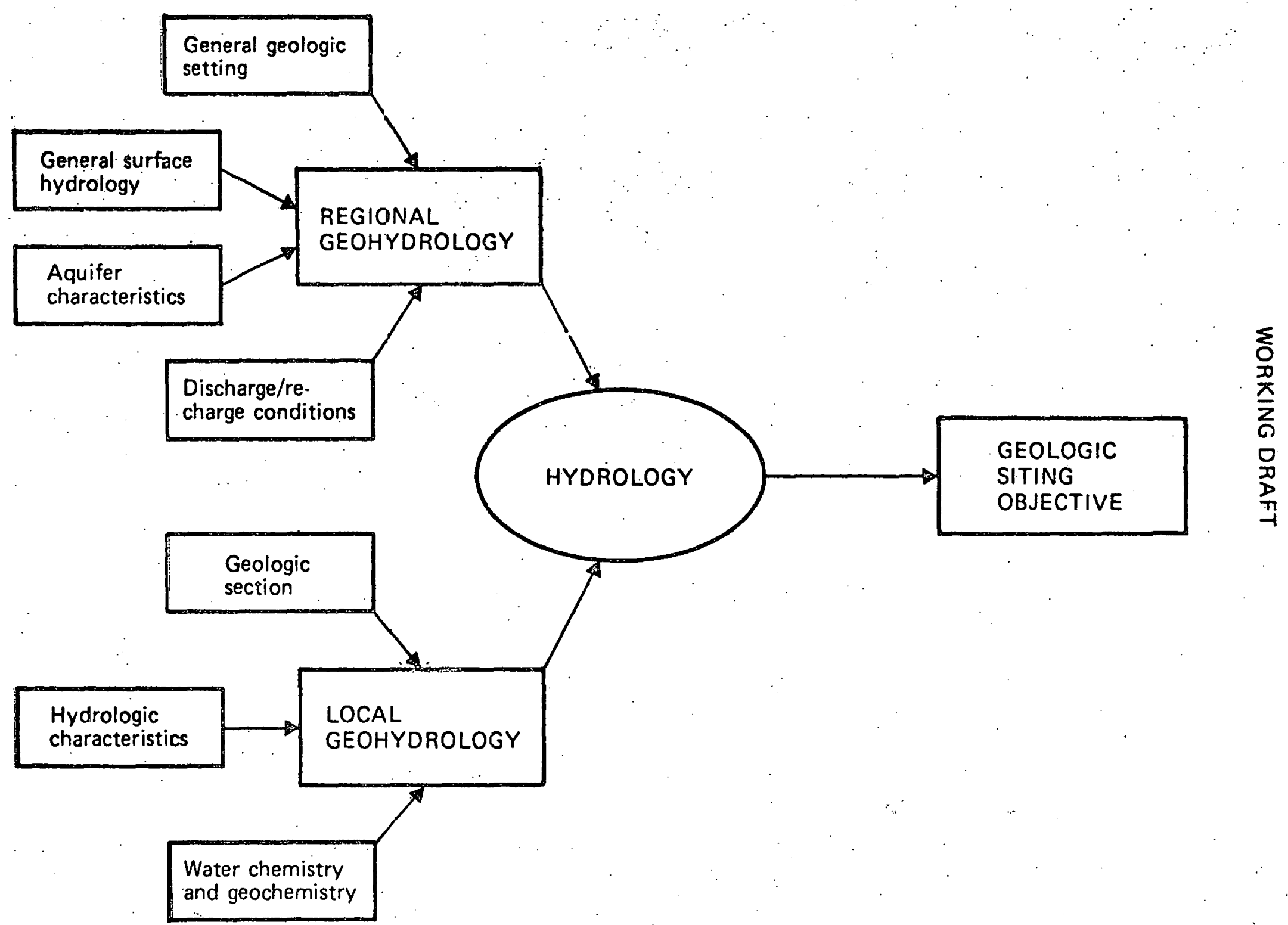

Figure 3.4 
The regional geohydrologic system needs to be evaluated, including the overall recharge/discharge conditions (groundwater budget). This information can be used to establish an interrelationship between existing hydrologic characteristics of the groundwater systems, water use, and the climatological conditions. These regional data are essential in considering the effects on the local geohydrology. However, it is not possible to assure projected performance of a candidate host rock. It is, therefore, important that a comprehensive performance monitoring program be developed.

\section{Relevant Factors}

Local Geohydrology. The local geohydrology consists of rock bodies that are grouped into aquifers and confining units, and/or combinations of interrelated aquifers and confining units. The usage of the term aquifer herein refers to a stratum of rock that contains permeable material and yields groundwater to wells.

Confining units range from strata of relatively impermeable rock that is capable of transmitting groundwater slowly but not in quantities sufficient to supply a well to impermeable rock that lacks the ability to hydraulically transmit groundwater. Rock of sufficient thickness and exhibiting impermeable properties from a hydrologic viewpoint are required for a candidate host rock.

In order to evaluate hydraulic connection between a candidate host rock and the surrounding geohydrologic regime it is necessary to examine the geologic, hydrologic, and chemical (water chemistry and geochemistry) data in a given area.

Data Needs. Initial information that is necessary to address the relative importance of the geohydrologic units within a given area is a determination of the geologic section. Information concerning the 


\section{WORKING DRAFT}

vertical arrangement of rock units, including depth and thickness, their gross mineralogy, and lateral variations, must first be gathered.

It is also necessary to consider natural resource development in a given area and its potential impact on hydraulic interconnections between units. Fast activities involved in the exploration or development of water, petroleum, or other minerai resources created bore holes, solution cavities; mines, etc., that may provide potential hydraulic pathways for the migration of fluids between aquifers. It is also necessary to consider the potential for future development of resources. Minerals that are not now considered of economic value may at some time in the future be exploited.

The geologic characteristics that need be considered are the following:

- Geologic section

- Gross mineralogy

- Openings in rock

- joints

- fractures

- partings

- solution cavities

- Porosity

- Permeability

- Depth

- Thickness

- Lateral changes

- extent

- thickness

- depth

- Natural resource development

- past activities

- bore holes 


\section{WORKING DRAFT}

- mines

- solution cavities

- projected future resource development

Hydrologic characteristics must also be considered. Of prime importance to the consideration of the interaction of the hydrologic regime and the host rock are the rate and direction of groundwater flow and existing or potential hydraulic interconnection.

The rate and direction of groundwater flow in an aquifer is controlled by the groundwater gradient existing within that aquifer and the permeability of the materials that make up that aquifer. The gradient is determined from the potentiometric surface of a given aquifer which is, in turn, developed from piezometric elevation data collected from monitoring wells designed to measure only that aquifer. Reliable values for permeability within aquifers are determined by well testing.

Hydraulic interconnections between aquifers (i.e., groundwater movement through confining units) may be detectable as a function of piezometric head changes in various aquifers or aquifer systems during field testing.

Additionally, coisideration should be given to the potential effect of repository-induced processes on the hydrologic characteristics of the host rock and/or its confining material and their potential effect as a driving force for the mobilization of groundwater, connate water, or released water from hydrated minerals.

Hydrologic characteristics for a local geohydrology study are:

- Flow rates and directions

- Gradients

- potentiometric surface

-depth to potentiometric surface

- Permeability

- Transmissivity 


\section{WORKING DRAFT}

- Porosity

- Effective porosity

- Confining conditions

- Storage coefficient (specific yield)

Repository-induced processes that may affect hydrologic characteristics are:

- Thermal expansion

- Thermal fracturing

- Mcvement of connate water

- heat as driving force

- Released water of hydration

- heat as driving force

- Vapor pressure

- lithostatic pressure

- hydrostatic pressure

In addition to evidence collected during hydrologic field testing, it may be possible to determine hydraulic connections between aquifers on the basis of groundwater chemistry. Groundwaters within a given aquifer or aquifer system, as a result of aquifer mineralogy, depositional environment; recharge source, or local phenomenon, may have distinctive chemical characteristics. This connection is inferred when waters of a chemical type are detected in another aquifer of different chemical type.

Water chemistry analysis also can be used as a tool to evaluate whether or not evaporites are undergoing the process of dissolution.

Typical water chemistry parameters include:

\section{General}

$-\mathrm{pH}$

- specific conductance

- temperature

- total dissolved solids 


\section{WORKING DRAFT}

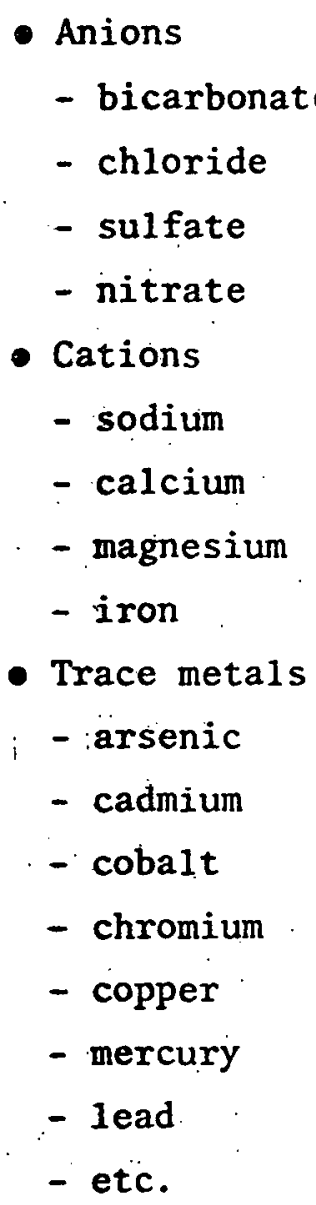

The varied geochenical characteristics of the confining beds and aquifers should be considered in terms of potential changes of permeability with time (i.e., interconnection of solution cavities), ion exchange capabilities of confining units, and release of water from hydrated minerals.

Geochemical characteristics that need to be considered include:

- Connate water

- Ion exchange

- Solubility

- Hydrated minerals

- Diagenises

- cementation

- secondary minerals 


\section{WORKING DRAFT}

\section{Data Sources.}

- Literature search

- Well inventory

- from field survey

- from agency records

- from owners and leasors

- from drilling contractors

- from newspapers, trade journals, and literature

If there is a meaningful statistical probability that an unknown bore hole exists in the repository site, develop new methods as required for bore hole location.

- Geological mapping

- Subsurface exploration

- exploration boring to augment available data and collect detailed subsurface data

- boring logs

- electric logs

- samples

- Monitoring wells

- Laboratory siudies (using subsurface exploration samples and monitoring samples)

- hydrologic characteristics

- permeability tests

- horizontal

- vertical

- water chemistry

- comprehensive chemical analysis of groundwater samples

- Field testing to determine aquifer coefficients

- transmissivity

- storage coefficient

- hydraulic connections between aquifers

- groundwater barriers 
Regional Geohydrology. The regional geohydrology needs to be evaluated relative to a given candidate host rock to assure that all conditions which may affect the local system are also considered. Potential concerns are fluctuations or long-term changes in the groundwater budget which may produce significant piezometric head variations. These could be the result of departures from existing climatic conditions or major changes in groundwater use patterns.

The regional geohydrologic conditions can be identified by examining (1) the general geologic setting with respect to hydrology, (2) the general surface hydrology, (3) the general aquifer characteristics, and (4) the overall recharge/discharge conditions.

Data Needs.

- General geologic settìng

- General geologic section

- gross petrology

- Tectonic interaction

- potential faulting

- groundwater barriers

- vertical pathways to surface

- existing folds

- groundwater barriers

- vertical pathways to surface

- potential regional warping, regional uplift, regional subsidence

- General surface hydrology

- influx of surface water into groundwater basin area

- influence of long-term climatological conditions

- arid cycles

- pluvial cycles

- glacial cycles 


\section{WORKING DRAFT}

- General aquifer characteristics

- major aquifers

- transmissivity

- storage coefficients (specific yield)

- Recharge/discharge conditions

It is necessary to know the areal extent of the recharge areas, influx of surface water into the recharge area, precipitation that directly infiltrates the recharge areas and volume of water injected into the system. Discharge is measured by the quantity of water that leaves the groundwater naturally as it flows into streams, rivers, or basin lakes, evapotranspires into the atmosphere, or is artificially removed by pumpage from wells.

- recharge areas

- infiltration

- percolation

- climate

- precipitation

- long-term changes

- surface water influx

- discharge areas

- natural

- groundwater use

- historic, projected

- piezometric head change

Data Sources.

- Regional geologic investigations

- literature studies

- general geologic mapping

- limited subsurface exploration

- regional and local tectonic evaluation 


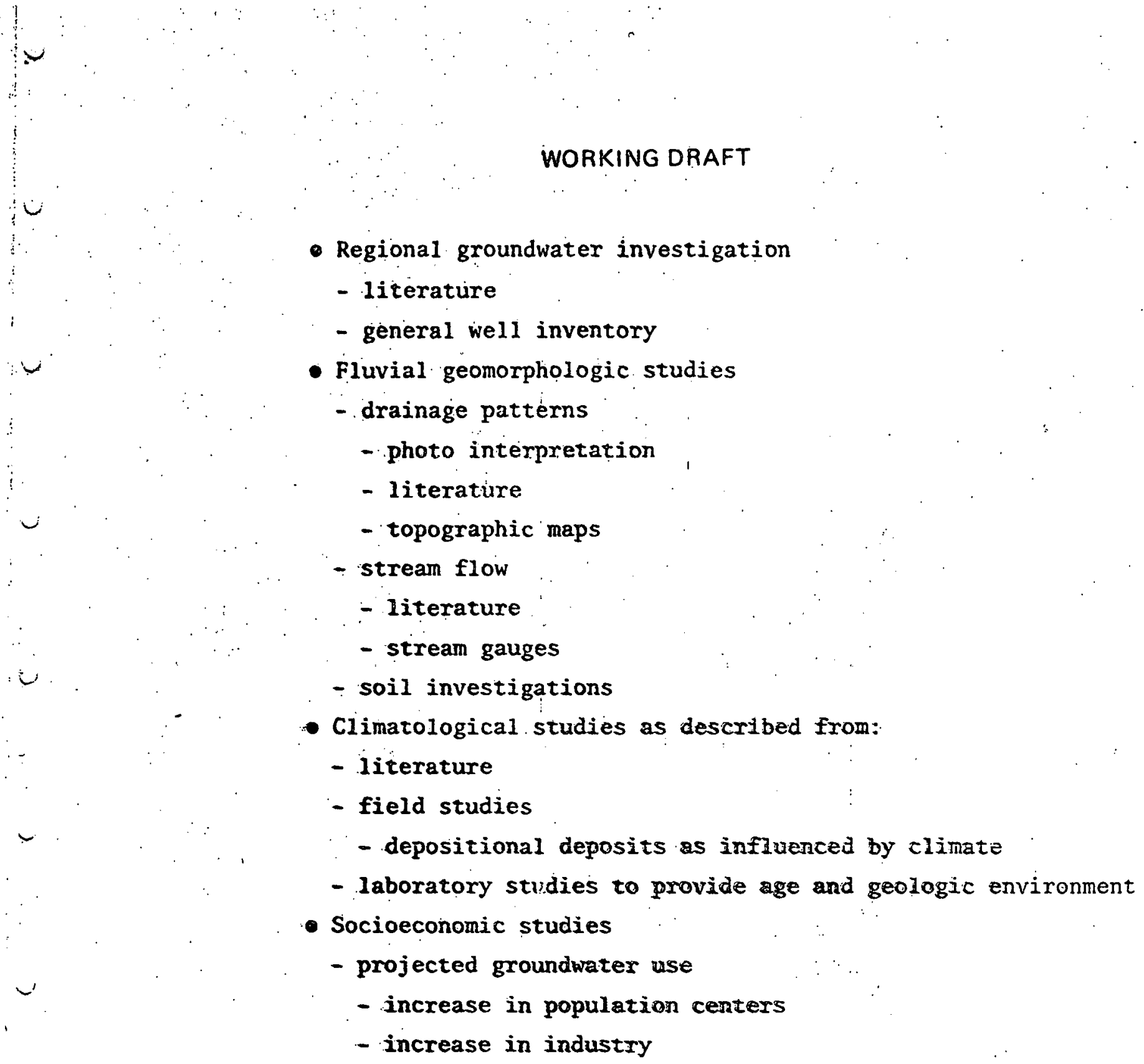

- Regional groundwater investigation

- likerature

- general well inventory

- Fluvial geomorphologic studies

- drainage patterns

- photo interpretation

- literature

- topographic maps

- stream flow

- Iiterature

- stream gauges

- soil investigations

- Climatological studies as described from:

- literature

- field studies

- depositional deposits as influenced by elimate

- laboratory studies to provide age and geologic environment

- Socioeconomic studies

- projected groundwater use

- increase in population certers

- increase in industry 


\section{WORKING DRAFT}

AN ILLUSTRATION OF AN APPROACH OF HOW GEOLOGIC SITING FACTORS ARE APPLIED TO QUALIFY A SITE

\subsection{INTRODUCTION}

This section presents an illustration of an approach of how the geologic siting factors are applied to qualify a site. The siting consideration selected for purposes of this illustration is depth for isolation. The relevant geologic siting factors are:

- stream erosion, wind erosion, and glacial erosion characterizing the natural surficial process

- stratigraphy and soils, climate and paleoclimate, and weathering characterizing the site environment

\subsection{APPROACH}

\subsubsection{General}

One of the most important points concerning impact assessments of geologic environment is that it does not lend itself easily to a precise analysis or analytical modeling that are common to most engineering problems. The major reasons are attributed firstly to the uniqueness of geologic environment which for practical purposes almost always depends on site-specific considerations; and secondly, the state of knowledge concerning the future behavior of the geologic environment is limited. Available approaches depend heavily on the experience of geologists to provide a reliable and accurate characterization of its historic 


\section{WORKING DRAFT}

geologic environment in order to furnish a basis to render judgements concerning the future.

For this illustration, the approach to qualify that the depth of host rock is adequate to assure geologic isolation involves the following steps:

o implement a regional geologic analysis to estabiish the relationship of base level to host rock

- establish the logic sequence of erosion assessment

o implement a site-specific analysis

\subsubsection{Regional Geologic Analysis}

A diagram of general flow of the regional geologic analysis is shown in Figure 4-1. The purpose of this analysis is to determine the relationship of the position of the regional base level with respect to the host rock. If the regional base level is located above the host rock, then stream erosion would not be a significant factor. Only the effects of wind and glacial erosion must be considered. On the other hand, if the base level is located below the host rock, then stream erosion together with wind and glacial erosion would all be factors that have to be considered.

In this analysis, the first task is to establish the base level in the region. This involves considerations of the changes of eustatic sea level with time, the geologic characteristics of the region including the major stream flow characteristics and gradients in the area. In addition, consideration of the geomorphology of the region would provide a good indication of the approximate elevation of the base level.

\subsubsection{Logic Sequence of Erosion Assessment}

A diagram of the general logic sequence of erosion assessment is illustrated in Figure 4.2 . If the assessment indicates that the rates of 


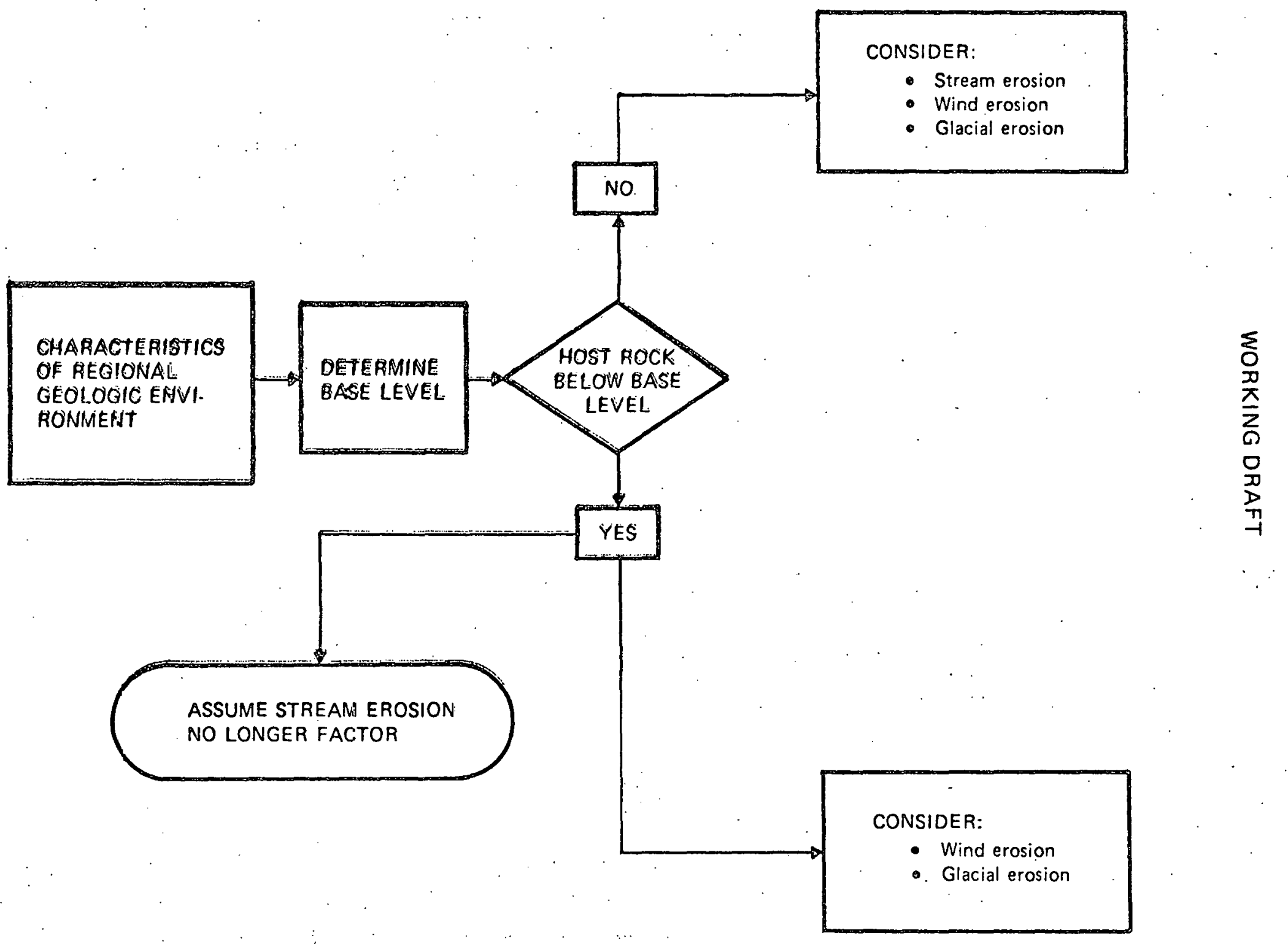

Figure 4.1. REGIONAL GEOLOGIC ANALYSIS TO DETERMINE RELATIONSHIP OF BASE LEVEL TO HOST ROCK 


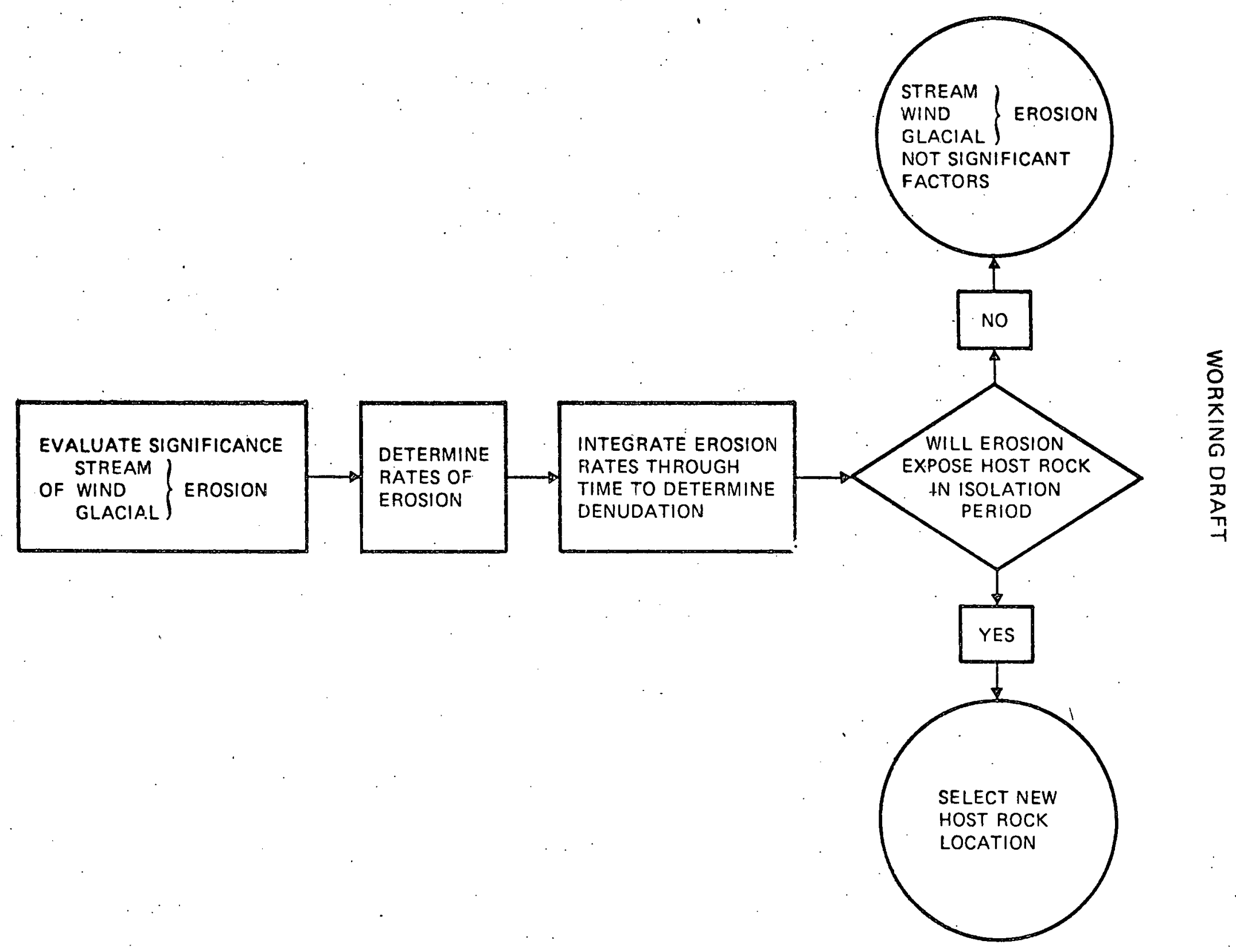

Figur. 4.2. GENERAL LOGIC SEQUENCE OF EROSION ASSESSMENT 


\section{WORKING DRAFT}

erosion were sufficiently small, such that the depth of denudation would not affect the host rock, then the processes of stream, wind, and glacial would not be a significant factor. On the other hand, if the host rock is located such that the consequences of erosion might encroach and expose the host rock, then a new host rock location would have to be selected.

\subsubsection{Site-Specific Analysis}

The key to the site-specific analysis lies in the assessment of the impact of the environmental energy on geologic system to arrive at reliable estimates of rates of erosion. Analysis of geologic systems depends heavily on the characteristics of each specific site. Approaches

- to site-specific analysis are almost always tailored to the unique attributes of each site. However, for purposes of this illustration, a general approach would involve an evaluation of historic geologic events and processes to establish empirical relationships, to be supplemented with analytical and field studies to establish baseline conditions for its present climates.

To extrapolate into the future, some data can be gained from erosion studies in areas which have rock types simil.ar to the host rock environment. Included in these studies would be thi postulation of climates that may occur at the repository during the period of waste isolation. The balance of the knowledge will come from a study of the various paleoclimates that have existed at the site. Experience and judgment will be required to interpret the results of studies of the past and the present in order to predict its future. 